\title{
Morphometric and Histopathologic Changes in Skeletal Muscle Induced for Injectable PLGA Microparticles
}

\author{
Cambios Morfométricos e Histopatológicos en el Músculo Esquelético Inducidos por \\ Microparticulas de PLGA Inyectables
}

\author{
"Luis Acuña; "Iván Suazo Galdames; **Daniela Zavando; ${ }^{* * *}$ Samanta Elgueta; ${ }^{* * * * * * * * *}$ \\ Luis Velásquez; ${ }^{* * * * * * * *}$ Cristian Vilos \& ${ }^{* * * * * *}$ Mario Cantín
}

\begin{abstract}
ACUÑA, L.; SUAZO, G. I; ZAVANDO, D.; ELGUETA, S.; VELÁSQUEZ, L.; VILOS, C. \& CANTÍN, M. Morphometric and histopathologic changes in skeletal muscle induced for injectable PLGA microparticles. Int. J. Morphol., 29(2):403-408, 2011.

SUMMARY: The administration of microencapsulated drug in a matrix acid poly(lactic-co-glycolic acid) (PLGA) by intramuscular (IM) in humans has been approved by the FDA for various applications though it is not clear what effect they have on the morphological parameters of muscle tissue. The aim of this study was to analyze the morphological changes in the skeletal muscle tissue with their use. We used 12 adult female Sprague Dawley rats (Rattus novergicus) that were injected into their right gastrocnemius muscle belly with: sterile vehicle solution $(\mathrm{G} 1, \mathrm{n}=4), 0.5 \mathrm{mg}$ PLGA microparticle $(\mathrm{G} 2, \mathrm{n}=4)$ and $0.75 \mathrm{mg}$ PLGA microparticle $(\mathrm{G} 3, \mathrm{n}=4)$, both dissolved in a sterile vehicle solution. At 14 days post injection the number and diameter of muscle fibers, the level of inflammation and histology appearance in terms of organization of muscle fibers, cellular distribution, tissue morphology and the presence of polymer waste were determined and the results between the groups compared. The administration of the compound in a single dose did not alter the morphometric parameters (number and diameter of muscle fibers) despite generating a mild inflammation in the tissue associated with the presence of polymeric residues, suggesting that the PLGA microparticles were well tolerated by the muscle tissue at concentrations tested ( 0.5 and $0.75 \mathrm{mg}$ ).
\end{abstract}

KEY WORDS: Skeletal muscle; Drug delivery; Polymeric microparticles; PLGA.

\section{INTRODUCTION}

The remarkable progress in biotechnology has contributed to the development of new drug delivery systems that increase the pharmacological effect and reduces side effects. The drug delivery systems commonly used are based on chemical modification of biomolecules with polyethylene glycol (PEGylation) by encapsulating the molecules in lipid (liposomes) or polymeric systems (microparticles) (Okada \& Toguchi, 1995). The best-known polymeric substances are poly(e-caprolactone), poly(lactic acid) and biodegradable aliphatic polyesters of hydroxy-functional acid as the poly(lactic-co-glycolic acid) (PLGA). The latter offers many advantages for drug delivery, such as reduced frequency of administration, reduced total dose required, decrease in adverse effects and, most importantly the controlled release of drugs in the treatment period desired, which can range from hours, weeks or months depending on the characteristics of the microspheres and the route of administration, in particular, the intramuscular (IM) route, which is the most used. The PGLA as the polymer matrix for microencapsulation of drugs has shown low toxicity, because it undergoes non-enzymatic hydrolysis of lactic and glycolic acids, which are metabolized to carbon dioxide and water and therefore harmless to the tissues (Tamber et al., 2005).

According to Kohane et al. (2002) and Colombo et al. (2004), the polymeric microparticles are harmful because they can cause inflammation, which depends on the nature of the material, particle size and type of tissue that is

* Universidad de Talca, Chile.

** Universidad Autónoma de Chile, Chile.

*** Faculty of Chemical and Biology, Universidad de Santiago, Chile.

***** Center for the Development of Nanoscience and Nanothechnology (CEDENNA), Santiago, Chile.

****** Universidad de La Frontera, Temuco, Chile.

The support from CONICYT under Proyecto BASAL FB0807 and Proyecto Tesis en la Industria TPI06 CONICYT and FONDECYT 1090598, are gratefully acknowledged. 
administered. For Haining et al. (2004) only particles less than 5-10 microns may be phagocytosed. The polymer's molecular weight also affects the length of time the tissue may affect the kinetics of drug release, as it is a determinant of the inflammatory response (Kohane et al., 2006). The FDA (Food and Drug Administration) in the United States has approved the administration of microencapsulated drugs in a PLGA matrix via IM in humans since 1989 for controlled drug release (Putney \& Burke, 1998; Bronzino, 2000; Jain, $2009,2011)$ in various applications. However, the effect of PLGA matrices on the morphological parameters of muscle tissue is not clear.

With this background, the objective of this study was to analyze the morphological changes in skeletal muscle tissue in terms of number, diameter and distribution of skeletal muscle fibers in Sprague Dawley rats subjected to a single IM injection of biodegradable PLGA microparticles as a system of drug delivery.

\section{MATERIAL AND METHOD}

We used poly(D,L-lactide-co-glycolide) with a 50:50 monomer ratio, ester-terminated and a viscosity 0.26-0.54 dl/g was purchased from Lactel Absorbable Polymers (Pelham, AL, USA). The poly(vinyl-alcohol) (PVA) was 8790\% hydrolyzed, average mol. Wt. of 30,000-70,000 SigmaAldrich (St. Louis, MO, USA). Dichloromethane (DCM) was purchased from Sigma-Aldrich (St. Louis, MO, USA).

Animals. We used 12 female Sprague Dawley (Rattus novergicus) healthy rats, between $250-300 \mathrm{~g}$, maintained in the animal facility of the Universidad de Talca. These arrangements were maintained with light/dark cycle of $12 /$ 12 hours at room temperature $22 \pm 21^{\circ} \mathrm{C}$ and humidity of $60 \pm 10 \%$, fed with commercial pellets and water ad libitum throughout the experiment. The animals were treated in compliance with the protocol of bioethics adopted by the Universidad de Talca, in accordance with the "Guide for Care and Use of Laboratory Animals" published by the U.S. National Institutes of Health (NIH Publication no. 85-23, http://grants.nih.gov/grants/olaw/olaw.htm).

\section{Procedures}

Preparation of microparticles. PLGA microparticles (MPs) were prepared by double emulsion-evaporation method (w/ $\mathrm{o} / \mathrm{w}$ ). In the first emulsion (w/o) $0.4 \mathrm{ml}$ of double distilled water solution was added into $1 \mathrm{~mL}$ of DCM containing 25 mg of PLGA, using a high-speed homogenizer which was emulsified at 35,000 rpm (Thermo Fisher Scientific,
Waltham, MA) Ultra-Turrax system. The second emulsion (w/o/w) was mixed with $2 \mathrm{~mL}$ of PVA $1 \%(1 \mathrm{mg} / \mathrm{mL})$ and emulsified by the same system. The particles were stirred (orbital shaker at $100 \mathrm{rpm}$ ) at room temperature overnight for the solvent evaporation. The microparticles were then collected by filtration. Once sieved, the microparticles were lyophilized and stored at $-20^{\circ} \mathrm{C}$.

Size and morphology of the microparticles characterization. The determination of the diameters of microparticles was made by analysis of images obtained by confocal microscopy and processed in the LSM Image Examiner software.

The morphology of PLGA microparticles was analyzed with scanning electron microscopy (SEM) on a Zeiss DSM 960 microscope equipped with a backscattered electron detector. The samples were lyophilized and deposited on a 300-mesh carbon-coated copper grid that had been previously hydrophilized under UV light (Electron Microscopy Sciences, Hat- field, PA) and coated with carbon, prior to examination.

Experimental procedure. The animals were randomly assigned to form study groups as follows:

Group 1 (G1): control injected with sterile vehicle solution $(\mathrm{n}=4)$

Group 2 (G2): experimental; injected with $0.5 \mathrm{mg}$ of PLGA microparticles in a sterile vehicle solution $(n=4)$.

Group 3 (G3): experimental; injected with $0.75 \mathrm{mg}$ of PLGA microparticles in a sterile vehicle solution $(n=4)$.

The dilution and homogenization of the microparticles in the vehicle solution for G2 and G3 groups was made with a stirrer for 15 seconds prior administration.

The rats were injected intramuscularly with a single puncture (day 0 ), using a disposable $1 \mathrm{ml}$ syringe graduated with a $20 \mathrm{G}$ needle on the right gastrocnemius muscle. The puncture site was marked and the entire solution was deposited in the fleshy portion of the muscle. The animals of all groups were kept in care according to individual animal management protocols for this research.

On day 14 post injection, rats of all the groups were anesthetized with ether and underwent euthanasia by cervical dislocation.

Sampling and histological processing. All samples were directly fixed in buffered formalin, embedded in paraffin and routinely processed for hematoxylin-eosin staining on 5-mm cross sections selected at random with four sheets for each piece, which were observed consistently through 
magnification at 100X using an Olympus CX21 microscope (Olympus ${ }^{\circledR}$ ) and analyzed by MicroImaging Software.

\section{Morphometric parameters:}

- Number of muscle fibers per $\mathrm{mm}^{2}$ is defined as the total number of muscle fibers that are recorded in an area of $1 \mathrm{~mm}^{2}$ with an increase of $100 \mathrm{X}$.

- Diameter of muscle fibers is defined as the diameter of the muscle fiber in the cross section, expressed in microns $(\mu \mathrm{m})$.

Based on these parameters descriptive statistics (mean, standard deviation) were obtained and the differences were evaluated by one-way ANOVA test, testing the equality of the variances by the Bartlett's test. In all the cases, the significance was $\mathrm{p}<0.05$.

Inflammatory Response. The degree of inflammatory response was evaluated histologically according to the system established by Setzen \& Williams (1997).

Histology. Morphological changes in organization of the muscle fibers and cellular distribution and tissue morphology were analyzed. The presence of microscopic polymeric residues, which were defined as any mass, at least partially, composed of microparticles was also observed.

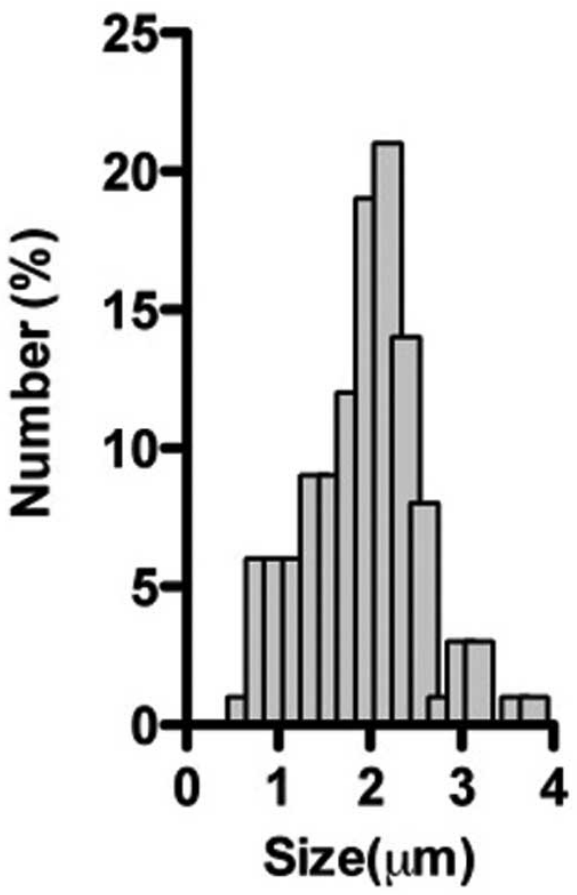

Fig. 1. Size distribution of PLGA microparticles obtained by confocal microscopy.

\section{RESULTS}

Our results showed that the size (diameter, $\mathrm{mm}$ ) of PLGA microparticles was $1.9 \pm 0.6(\mathrm{~mm})$, and normal particle size distribution with a range betwen 0.7-3.7 (mm) as shown the Figure 1.

The TEM images showed polymeric spherical microosized particles with smooth surface (Fig. 2).

The average number of muscle fibers counted in the three groups was similar, although the variance was significantly different (Bartlett test $\mathrm{p}=0.0375$ ), the ANOVA p value was 0.9454 . Table I shows the descriptive statistics for the variable number of muscle fibers per $\mathrm{mm}^{2}$. Table II shows the results for the variable diameter of muscle fibers. When the means are

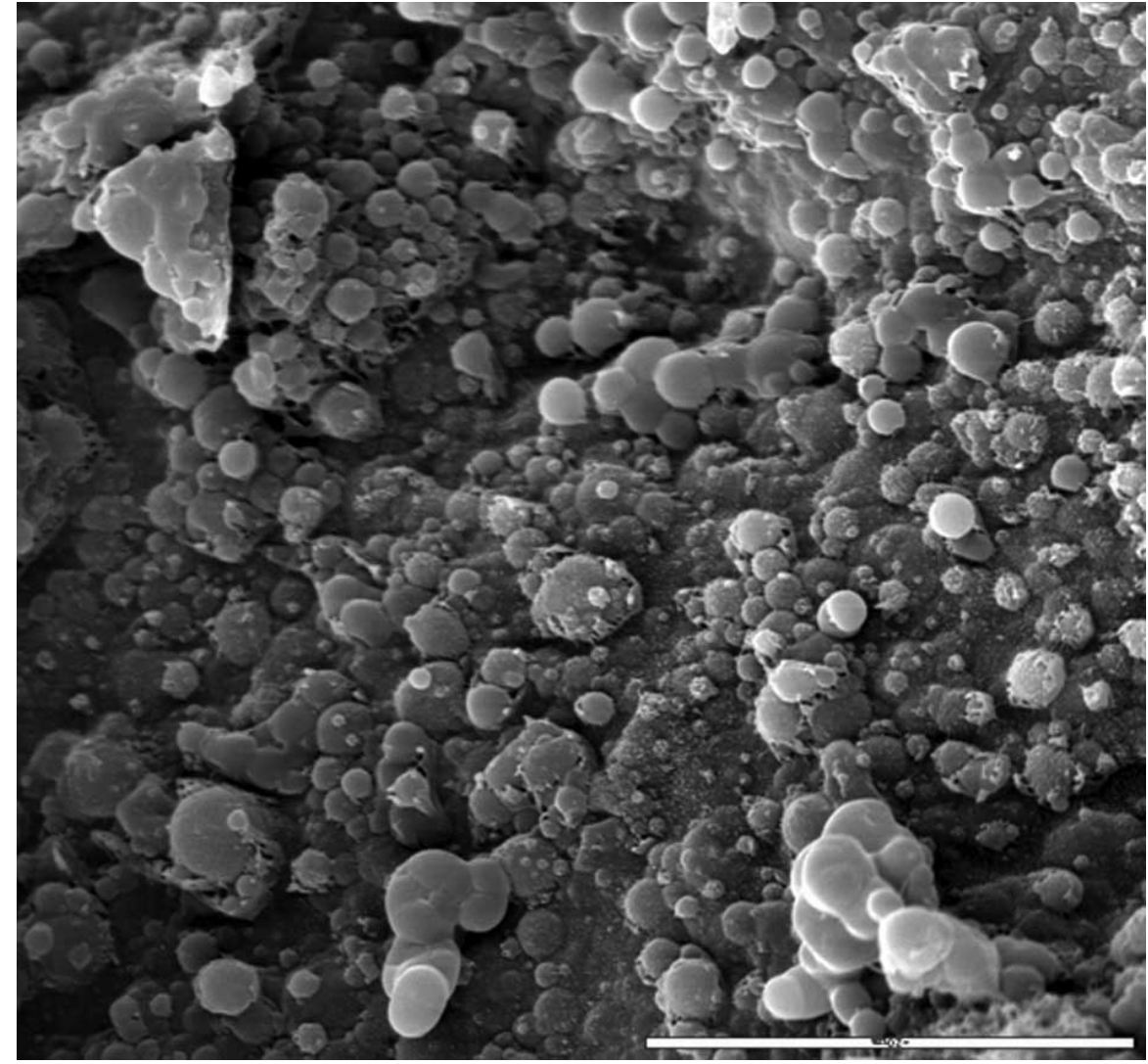

Fig. 2. TEM image of PLGA microparticles (scale $20 \mu \mathrm{m}$ ). 
Table I. Descriptive statistics of the number of fibers per $\mathrm{mm}^{2}$ in the total sample $(100 \mathrm{x})$.

\begin{tabular}{lccc}
\hline & G1 & G2 & G3 \\
\cline { 2 - 4 } Minimum & 19.0 & 18.0 & 18.0 \\
Maximum & 20.0 & 20.0 & 20.0 \\
Mean & 19.5 & 19.0 & 18.75 \\
SD & 0.57 & 0.81 & 0.95 \\
\hline
\end{tabular}

Table II. Descriptive statistics for the variable diameter of muscle fibers. The values are expressed in microns.

\begin{tabular}{lccc}
\hline & G1 & G2 & G3 \\
\cline { 2 - 4 } Minimum & 589.2 & 589.2 & 600.8 \\
Maximum & 642.5 & 646.4 & 641.3 \\
Mean & 623.8 & 625.0 & 626.0 \\
SD & 14.54 & 16.52 & 11.03 \\
\hline
\end{tabular}

not significant there are differences between the groups (ANOVA $\mathrm{p}=0.8597$ ).

No inflammatory response was found in G1, whereas G2 and G3 showed a mild inflammatory response in all the samples.

In all the groups, muscle fibers were observed with a uniform architecture, well-established location with eccentric nuclei, similar sizes and regular distribution of fibers. Similarly, there were no central core muscle fibers (muscle fibers youth) (Figs. $3 \mathrm{~A}, \mathrm{~B}$ and C). In groups injected with microparticles (G3 and G4), the connective tissue showed a regular pattern, but with the mild inflammatory infiltrate, in which macrophages and lymphocytes were predominant isolates. There were no areas of fibrosis or necrosis (Fig. 4), but in all cases, polymeric residues were distributed and observed in isolation in the connective tissue surrounded by inflammatory infiltrate (Fig. 5).

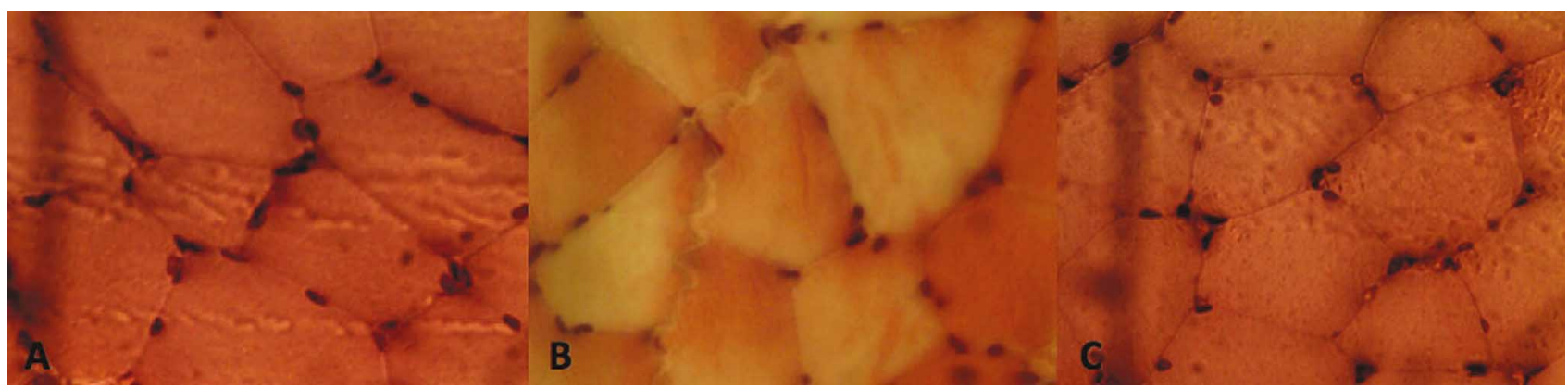

Fig. 3. Gastrocnemius muscle of rat (100x increase) there is a uniform tissue structure with eccentric nuclei location, similar diameters and regular distribution of fibers. A: G1: B: G2; C: G3.

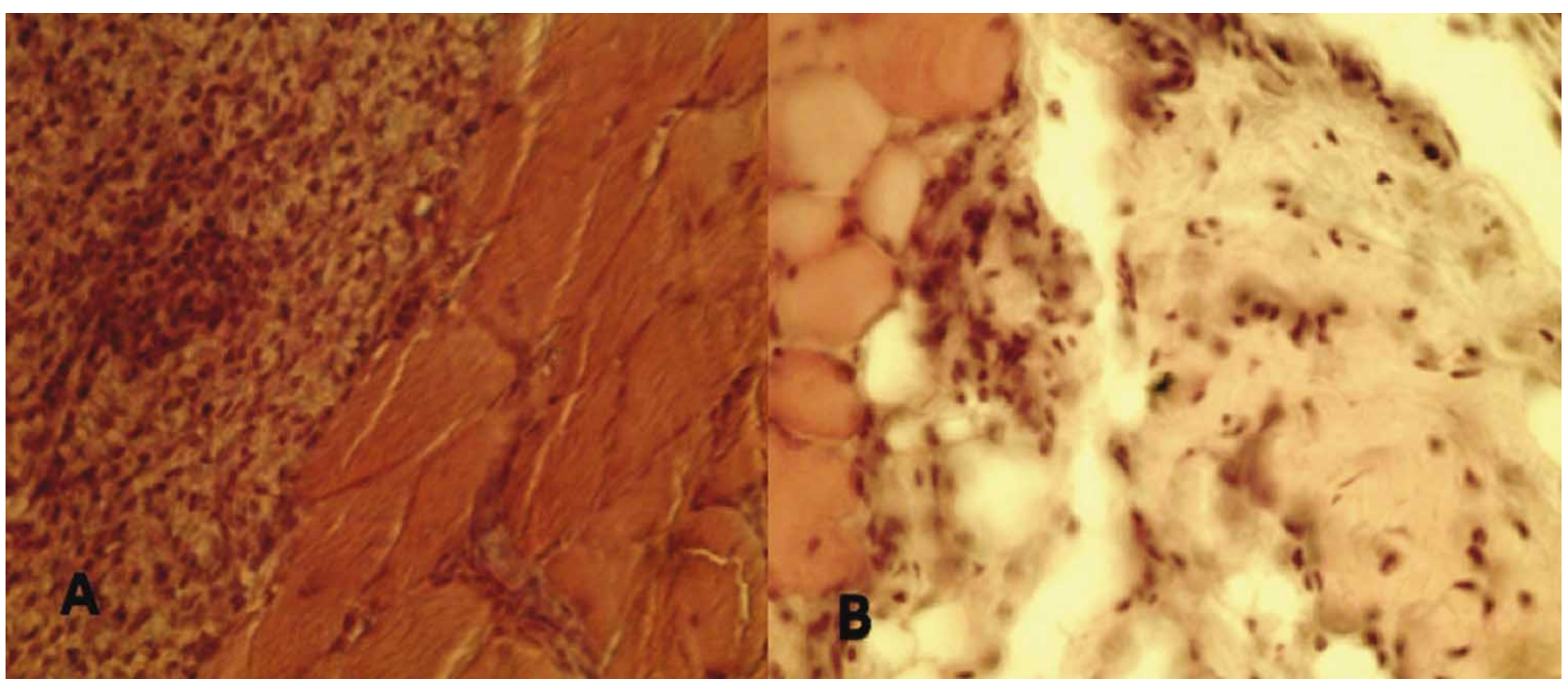

Fig. 4. Inflammatory response and muscle response 2 weeks after injection. Reaction of PLGA microparticles in the adjacent connective tissue showed mild inflammatory infiltrate without areas of fibrosis or necrosis. A (40X): G2, B (40X): G3 


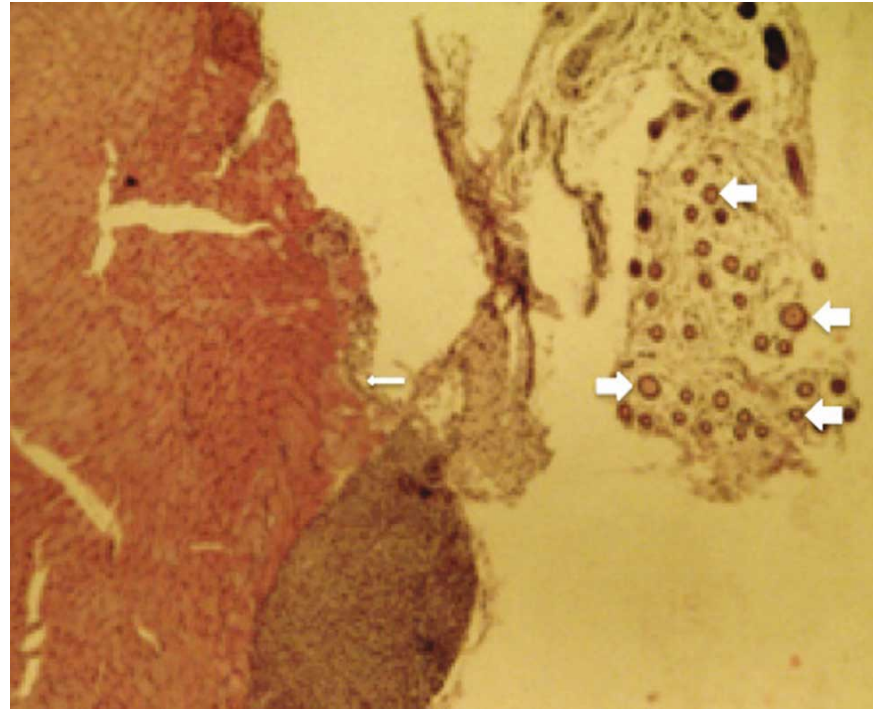

Fig. 5. Tissue reaction to PLGA microparticles 2 weeks after injection. Polymer residues are observed in the adjacent connective tissue associated with a mild inflammatory infiltrate (B, 4X: G3).

\section{DISCUSSION}

In this study, we evaluated the response of striated skeletal muscle tissue to the application of PLGA microspheres for sustained release. Our results show that the administration of the compound in a single dose does not alter the morphometric parameters (number and diameter of muscle fibers) despite generating a mild inflammation in the tissue associated with the presence of microscopic polymer waste. This reaction is quite safe in the muscle tissue, probably due to the PLGA matrix degradation that occurs by a uniform breaking of their bonds without the involvement of enzymatic activity. As it is a process of hydrolysis, the degradation of the PLGA lactic and glycolic acid that enter the tricarboxylic acid pathway is metabolized and eliminated from the body as carbon dioxide and water (Giunchedi et al., 1998; Jain, 2000).

For Jang \& Shea (2006), IM injection of polymeric microspheres loaded with plasmid DNA causes foreign body reaction characterized by an initial inflammatory infiltrate composed of neutrophils and macrophages. In this sense, Kohane \& Langer (2010) indicate that polymeric microparticles are inert and cause no tissue reaction that coincides with acute inflammation histologically and it does not differ considerably from muscle tissue response to conventional drug administration via IM. However, the presence of waste for more than two weeks induces changes in the composition of inflammatory cells to include macrophages and lymphocytes. Of course, based on size, the particles can induce the formation of foreign body giant cells that are surrounded by a fibrous capsule of fibroblasts. In another model, Horie et al. (2010) observed no significant presence of inflammatory cells in the middle ear mucosa of pigs after local application of PGLA microparticles loaded with lidocaine in the cochlea for the treatment of tinnitus.

Rungseevijitprapa et al. (2008) investigated the potential myotoxicity of the solvents used in the preparation of polymer solutions, emulsions, solvents and formulations with different proportions of phase for the formation of micro-systems in vitro and in vivo in skeletal muscle, confirming good biocompatibility of the muscle to PLGA formulations.

On the other hand, histological analysis of muscles injected with microspheres found no areas of fibrosis or necrosis. In addition, there were no young muscle fibers, which according to Parra et al. (2007) reflect the tissue regenerative activity, inferred by its absence, indicating that there was no recent tissue damage.

In all rats injected with micro-PLGA showed the presence of polymeric residues isolated from adjacent connective tissue. These results agree with the study of Kohane et al. (2002), who observed the presence of isolated microspheres deposits surrounded by foreign body giant cells two weeks after injection. According to Jang \& Shea, the distribution of the microparticles in the tissue varies depending on the polymer's molecular weight. At two days post injection, the microspheres of high and low molecular weight were found in clusters within the tissue occupying regions and ranging in size from about 0.2 to $1.3 \mathrm{~mm}$. However, at 50 days post injection, microspheres with high molecular weight builds up in long clusters, while low molecular weight microspheres were distributed along the injection site in small clusters. Furthermore, the size of the microparticles allowed a lower inflammatory response. In our study, we used a formulation of PLGA microparticles between 0.5 and 10 microns in diameter confirming the findings of Haining et al., who claimed that particle size determines in part the nature of the inflammatory response. Our particles, between 0.7-3.7 microns can be easily degraded, while those of a larger size are not necessary for the processes of phagocytosis.

The mild inflammatory response observed in this study, together with the absence of the foreign body reaction and maintenance of the morphometric parameters suggest that the PLGA microspheres are well tolerated by the muscle tissue at concentrations of 0.5 and $0.75 \mathrm{mg}$. This finding allows its use for injectable intramuscular administration, permitting more irritating substances and managing higher volumes of drugs than that of the intravenous route. 
ACUÑA, L.; SUAZO, G. I; ZAVANDO, D.; ELGUETA, S.; VELÁSQUEZ, L.; VILOS, C. \& CANTÍN, M. Cambios morfométricos e histopatológicos en el músculo esquelético inducidos por microparticulas de PLGA inyectables. Int. J. Morphol., 29(2):403-408, 2011.

RESUMEN: La administración de fármacos encapsulados en micropartículas de ácido poli-láctico/glicólico (PLGA) por vía intramuscular (IM) ha sido aprobada por FDA para su uso en seres humanos con variadas aplicaciones, no estando claro el efecto que tienen sobre los parámetros morfológicos del tejido muscular. El objetivo de este estudio fue analizar los cambios morfológicos en el tejido muscular esquelético. Se utilizaron 12 ratas (Rattus novergicus) hembras de la cepa Sprague Dawley, las cuales fueron inyectadas en el vientre del músculo gastrocnemio derecho con: solución vehículo estéril $(\mathrm{G} 1, \mathrm{n}=4)$ y con micropartículas $0,5 \mathrm{mg}(\mathrm{G} 2, \mathrm{n}=4)$ y $0,75 \mathrm{mg}$ de PLGA $(\mathrm{G} 3$, $\mathrm{n}=4)$ ambas disueltas en solución vehículo estéril. A los 14 días post inyección se determinó el número y diámetro de fibras musculares, el nivel de inflamación y el aspecto histológico en términos de organización de fibras musculares, así como la distribución y morfología celular del tejido conjuntivo y presencia de residuos poliméricos, comparándose los resultados entre los grupos de estudio. La administración del compuesto en una sola dosis no modificó los parámetros morfométricos (número y diámetro de las fibras musculares), a pesar de generar una inflamación leve en el tejido, asociado a la presencia de residuos poliméricos, lo que sugiere que microesferas de PLGA son bien toleradas por el tejido muscular en las concentraciones probadas $(0,5$ and $0,75 \mathrm{mg})$.

PALABRAS CLAVE: Músculo esquelético; Liberación de fármacos; Micropartículas poliméricas; PLGA.

\section{REFERENCES}

Bronzino, J. The Biomedical Engineering Handbook. $2^{\text {nd }}$ ed. Boca Ratón, CRC Press, 2000. V. 1.

Colombo, G.; Langer, R. \& Kohane, D. Effect of excipient composition on the biocompatibility of bupivacaine-containing microparticles at the sciatic nerve. Inc. J. Biomed. Mater., 6519, 2004.

Giunchedi, P.; Conti, B.; Scalia, S. \& Conte, U. In vitro degradation study of polyester microspheres by a new HPLC method for monomer release determination. J. Control Release, 56(13):53-62, 1998.

Haining, W. N.; Anderson, D. G.; Little, S. R.; von Bergwelt-Baildon, M. S.; Cardoso, A. A.; Alves, P.; Kosmatopoulos, K.; Nadler, L. M.; Langer, R. \& Kohane, D. S. pH-triggered microparticles for peptide vaccination. J. Immunol., 173:2578-85, 2004.

Horie, R. T.; Sakamoto, T.; Nakagawa, T.; Tabata, Y.; Okamura, N.; Tomiyama, N.; Tachibana, M. \& Ito, J. Sustained delivery of lidocaine into the cochlea using poly lactic/glycolic acid microparticles. Laryngoscope, 120(2):377-83, 2010.

Jain, R. A. The manufacturing techniques of various drug loaded biodegradable poly(lactide-co-glycolide) (PLGA) devices. Biomaterials, 21(23):2475-90, 2000.

Jain, KK. Role of nanobiotechnology in the development of personalized medicine. Nanomedicine, 4(3):249-52, 2009.

Jain, K. K. The role of nanobiotechnology in the development of personalized medicine. Med. Princ. Pract., 20(1):1-3, 2011.

Jang, J. \& Shea, L. Intramuscular delivery of DNA releasing microspheres: Microsphere properties and transgene expression. J. Control Release., 112(1):120-8, 2006.

Kohane, D. S. \& Langer R. Drug delivery and translation. Drug Delivery and Translational Research, 1(1):4-6, 2010.

Kohane, D. S.; Lipp, M.; Kinney, R.; Anthony, D.; Lotan, N. \& Langer, R. Biocompatibility of lipid-protein-sugar particles containing bupivacaine in the epineurium. J. Biomed. Mater. Res., 59:450-9, 2002.

Kohane, D.; Tse, J.; Yeo, Y.; Padera, R.; Shubina, M. \& Langer, R. Biodegradable polymeric microspheres and nanospheres for drug delivery in the peritoneum. J. Biomed. Mat. Res., 77(1):351-61, 2006.

Okada, H. \& Toguchi, H. Biodegradable microspheres in drug delivery. Crit. Rev.Ther. Drug Carrier Syst., 12:1-99, 1995.

Parra, L. R.; Matamala, V. F. \& Silva, M. H. Efecto morfológico de la irradiación láser AsGa en el músculo esquelético de rata. Int. J. Morphol., 25(1):43-50, 2007.

Putney, S. D. \& Burke, P. A. Improving protein therapeutics with sustained-release formulations. Nat. Biotechnol., 16(2):1537, 1998

Rungseevijitprapa, W.; Brazeau, G. A.; Simkins, J. W. \& Bodmeier, R. Myotoxicity studies of $\mathrm{O} / \mathrm{W}$-in situ forming microparticle systems. Eur. J. Pharm. Biopharm., 69(1):126-33, 2008.

Setzen, G. \& Williams, E. Tissue response to suture materials implanted subcutaneously in a rabbit model. Plast. Reconstr. Surg., 100(7):1788-95, 1997.

Tamber, H.; Johansen, P.; Merkle, H. P. \& Gander, B. Formulation aspects of biodegradable polymeric microspheres for antigen delivery. Adv. Drug. Deliv. Rev., 57(3):357-76, 2005.

\section{Correspondence to: \\ Dr. Mario Cantín L. \\ Depto. de Odontología Integral \\ Facultad de Medicina \\ Universidad de La Frontera \\ CHILE}

Email: mcantin@ufro.cl
Received: 12-01-2011

Accepted: 14-03-2011 